\title{
Random Blood Glucose Levels Among Pregnant Women Attending Ante-Natal Clinic in Ahmadu Bello University Teaching Hospital, Shika-Zaria, Nigeria.
}

\author{
${ }^{1}$ Bako I. Gaya ${ }_{2}^{1}$ Isa A. Imam, ${ }^{2}$ Hassan Abdulaziz, ${ }^{1}$ Abdulrauf A. Rukayya. \\ ${ }^{3}$ Madugu N. Hauwa \\ ${ }^{I}$ Department of Human Physiology, Faculty of Medicine, Ahmadu Bello University Zaria, Nigeria. \\ ${ }^{2}$ Department of Heamatology, Faculty of Medicine, Ahmadu Bello University Teaching Hospital, Shika-Zaria, Nigeria. \\ ${ }^{3}$ Department of Gynaecology, Faculty of Medicine, Ahmadu Bello University Teaching Hospital, Shika-Zaria, Nigeria.
}

\begin{abstract}
The frequency of hyperglycemia among pregnant women attending ante-natal clinic was examined along with age and parity to assess the incidence of gestational diabetes mellitus. Random blood glucose levels in first, second and third trimesters of pregnant women was evaluated by the glucose-oxidase principle using the Easy Touch ${ }^{\circledR}$ blood glucose monitoring system. A survey method was adopted for the study while purposive sampling technique was employed to generate data using questionnaire. The random blood glucose levels for first trimester $(86.3 \pm 12 \mathrm{mg} / \mathrm{dL})$, second trimester $(93 . \pm 12 \mathrm{mg} / \mathrm{dL})$ and third trimester $(108 \pm 18 \mathrm{mg} / \mathrm{dL})$. The random blood glucose level based on age range 18-22 (92 $\pm 19 \mathrm{mg} / \mathrm{dL}), 23-27$ (94 $\pm 18 \mathrm{mg} / \mathrm{dL}), 28-32$ $(99 \pm 16 \mathrm{mg} / \mathrm{dL}), 33-37(97 \pm 17 \mathrm{mg} / \mathrm{dL})$ and $38-42(94 \pm 15 \mathrm{mg} / \mathrm{dL})$. The random blood glucose level based on parity $P_{0}(88.4 \pm 16 \mathrm{mg} / \mathrm{dL}), P_{1}(100 \pm 20 \mathrm{mg} / \mathrm{dL}), P_{2}(99 \pm 19 \mathrm{mg} / \mathrm{dL}), P_{3}(99 \pm 13 \mathrm{mg} / \mathrm{dL})$ and $P_{4}(96 \pm 13 \mathrm{mg} / \mathrm{dL})$. The random blood glucose levels increased significantly in third trimester and the value is low among nulliparous women. The increasing frequency of blood glucose level in third trimester may predispose the women to hyperglycemia or gestational diabetes. Random blood glucose level tends to increase during parity and at advanced reproductive age.
\end{abstract}

Keywords: Hyperglycemia, Gestational diabetes, random blood glucose, pregnancy.

\section{Introduction.}

Pregnancy is a delicate stage where maternal adaptation occurs early to provide a good upshot for both the mother and the fetus. These physiological changes occur at different rates throughout the whole body which allow the pregnant woman to accumulate additional energy in preparation for labour and gestation. ${ }^{16}$ Fluid retention is one of the most fundamental systemic changes of normal pregnancy which accounts for between 8$10 \mathrm{~kg}$ of the average maternal weight gain of $11-13 \mathrm{~kg}$. Increase in secretion of metabolic hormones during pregnancy particularly thyroxin and adreno-cortical hormones increase the metabolic rate by about $15 \%$ during the third trimester. Protein anabolism occurs, blood glucose levels increase and about 3-4 kg of fat is deposited in the maternal body, and this increases blood cholesterol levels. ${ }^{11,23}$ Increase in blood cholesterol levels impair insulin-mediated entry of glucose into the cells thus resulting in hyperglycemia of variable severity., ${ }^{3,4}$ Pregnancy is usually diabetogenic due to the effects of some pregnancy associated hormones such as cortisol and human chorionic somatomammotropin and $1-14 \%$ of pregnant women develop gestational diabetes mellitus. Gestational diabetes mellitus can result from high blood glucose - which is due to the effect of hormones of pregnancy and adipose tissue. ${ }^{1,2}$ Gestational diabetes is associated with a range of maternal perinatal morbidities and mortality including fetal macrosomia (20\%), hyperinsulinaemia and hypoglycaemia, but may also program childhood obesity and adult onset cardiovascular disease and diabetes. ${ }^{19,20}$ The incidence of gestational diabetes is still in the increase coupled with long-term pathological consequences it may have on both mother and the child. ${ }^{17,30}$ The evaluation of random blood glucose during pregnancy is rapidly recognized so that Hyperglycemia can be effectively managed before metamorphosing to gestational diabetes.

\subsection{Materials.}

\section{Materials and Methodology.}

The following materials were used for the research work; Glucometer using the accu-test active blood glucose monitoring system, blood lancet, Cotton wool and methylated spirit, and 90 subjects pregnant women.

\subsection{Data Collection.}

The study was compiled with the ethical committee guidelines of Ahmadu Bello University Teaching Hospital, Zaria. The procedures followed were in accord with the ethical standards of Ahmadu Bello University, Zaria, Nigeria with registration number ABUTH/PGO/COMM/0036. The data of ninety pregnant women 
attending Ante-natal Clinics in Ahmadu Bello University Teaching Hospital, Shika-Zaria, was collected in July 2013 using systematic random sample. The collection of random blood glucose level of the subjects was categorized into first trimester, second trimester and third trimester using questionnaire. Questionnaire was used because it permits anonymity, and contained an open and closed end question which was divided into biodata of the respondents, information about the pregnancy and the random blood glucose level in $\mathrm{mg} / \mathrm{dl}$.

\subsection{Climate of the Research Area.}

Zaria is geographically located between the longitude $11^{\circ} 3^{\prime} \mathrm{N}$, and latitude $7^{\circ} 42^{\prime} \mathrm{E}$. It has mean annual rainfall of $1000 \mathrm{~mm}$, mean annual temperature of $27^{\circ} \mathrm{C}$, height of $670 \mathrm{~m}$ above sea level and $664 \mathrm{~km}$ away from the sea, with a dry and wet season. ${ }^{15}$

\subsection{Determination of Random Blood Glucose.}

Random blood glucose is blood glucose level taken from a non-fasting subject at any time. Determination of the blood glucose level was done by the glucose-oxidase principle using the Glucometer Easy Touch $^{\circledR} \mathrm{G}$ blood glucose monitoring system. ${ }^{9,10}$ A drop of blood will be obtained from the subjects after pricking the fingertip. The drop of blood will be applied to the paper test strips of the glucometer, the reading will then be taken in six seconds by the glucometer and the result expressed in $\mathrm{mg} / \mathrm{dl}$.

\subsection{Data Analysis.}

All data are expressed as mean \pm standard of error mean (Mean \pm S.E.M.). The data obtained were analyzed using $\mathrm{z}$ - test, SPSS package version 20.0 and post hoc test for multiple comparisons. The $(\mathrm{P}<0.05)$ was accepted as significant

\section{Results.}

The random blood glucose level in 90 pregnant women grouped into first, second and third trimesters are shown in the figures. The random blood glucose levels in pregnancy showed a significant increase between the trimesters as the pregnancy advances. The second $(93 \mathrm{mg} / \mathrm{dL})$ and third $(108 \mathrm{mg} / \mathrm{dL})$ trimesters increased significantly $(\mathrm{P}<0.05)$ as the pregnancy moves towards termination period figure 1. Random Blood Glucose levels in age range of pregnant women showed that from $18-23$ years $(92 \pm 19 \mathrm{mg} / \mathrm{dL})$ it moved up to its peak at 28-32 years $(99 \pm 16 \mathrm{mg} / \mathrm{dL})$ and dropped down to $38-42$ years $(94 \pm 15 \mathrm{mg} / \mathrm{dL})$ figure 2 . The random blood glucose level in relation to multiparous pregnant women showed high random blood glucose levels Pn (96$100 \mathrm{mg} / \mathrm{dL})$ and a low non parous pregnant women $\mathrm{P} 0(88.4 \pm 15 \mathrm{mg} / \mathrm{dL})$ value in figure 3.

IV. Figures.

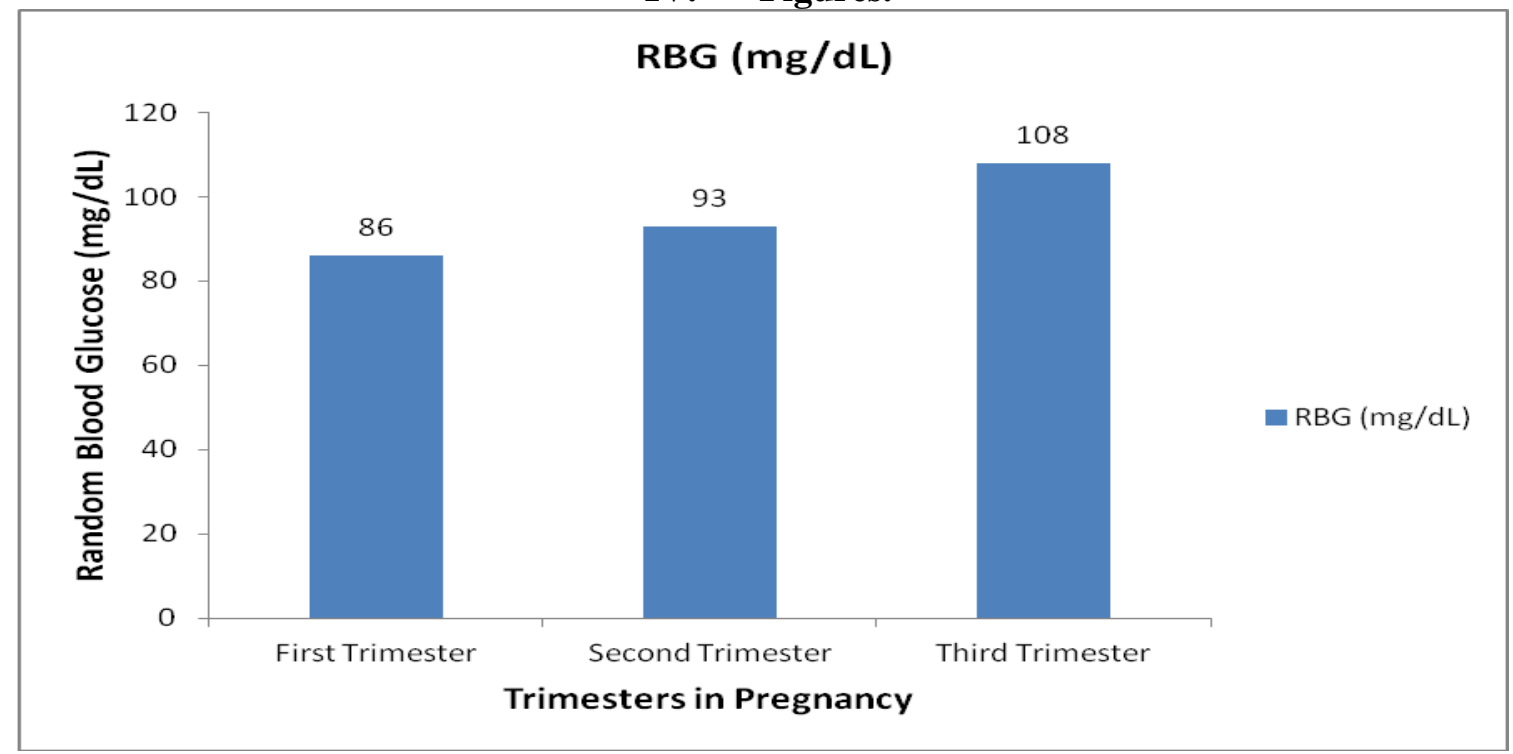

Figure 1 Random Blood Glucose levels in the three trimester of pregnancy. 


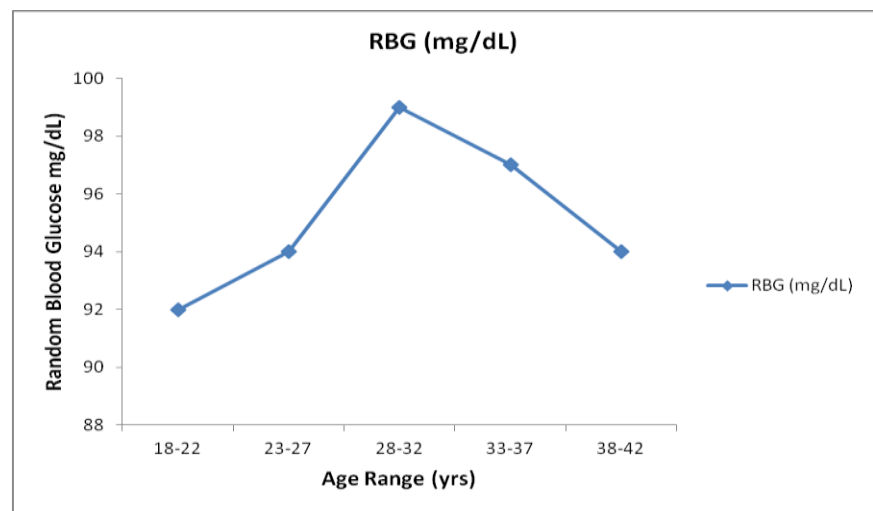

Figure 2 Random Blood Glucose levels in age range of pregnant women.

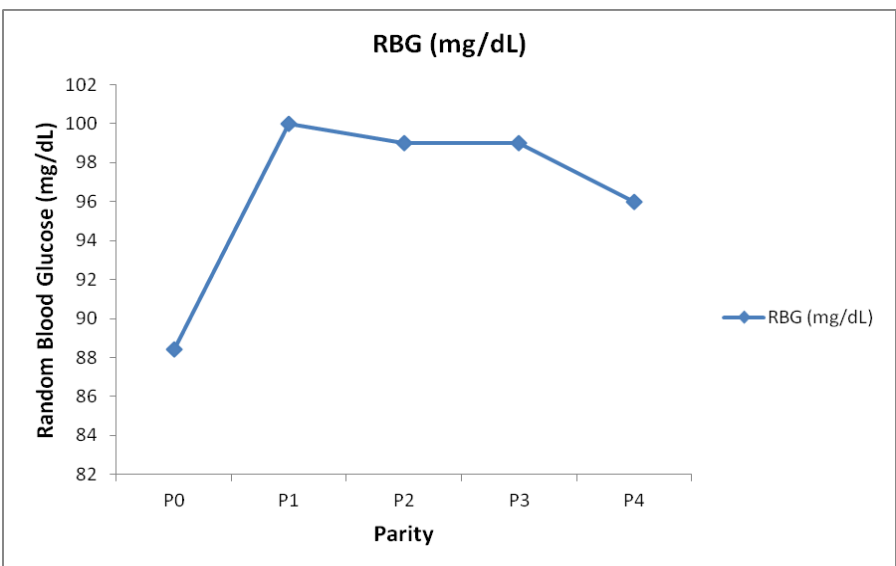

Figure 3 Random Blood Glucose levels in relation to parity.

\section{Discussion.}

The high prevalence of diabetes globally and its increasing frequency in women of gestational age are generating new research data on the relationship between hyperglycemia and adverse pregnancy outcomes. ${ }^{35,39}$ Pregnancy is a delicate stage where maternal adaptation occurs early to provide a favorable atmosphere for both the mother and the fetus. ${ }^{18}$ These physiological changes occur at different phases throughout the whole body which allow the pregnant woman to store additional energy in preparation for labor and delivery. ${ }^{37}$ The random blood glucose of the pregnant women assessed by categorizing them into first, second and third trimester showed that there was an increase in the blood glucose level with the progression of the pregnancy. ${ }^{12,29}$ The random blood glucose levels for second and third trimesters increased significantly when compared to the one of first trimester. Pregnancy is associated with several changes in body systems with fluid retention and increase in blood volume as one of the most fundamental systemic changes of normal pregnancy. ${ }^{15,32}$ Certainly, it is obvious that the hormonal interplay immediately after fertilization makes the hormones to be the initial primary changes in pregnancy. ${ }^{14}$ The human chorionic gonadotropin (hCG) secreted by the corpus luteum of pregnancy, progesterone, relaxin and human chorionic somatomammotropin (hCS) secreted by syncytiotrophoblast all increases to maintain the possible changes in pregnancy. ${ }^{8,10}$ During first and early second trimesters of pregnancy, glucose tolerance is normal or slightly improved and peripheral (muscle) sensitivity to insulin and hepatic basal glucose production is normal. ${ }^{7,9}$ These could be caused by the increased maternal estrogen and progesterone in early pregnancy which increase and promote pancreatic B-cell hyperplasia (Expansion of betacell mass in response to pregnancy) causing an increased insulin release. ${ }^{27}$ This explains the rapid increase in insulin level in early pregnancy, in response to insulin resistance. In the second and third trimester, the incessant increase in the feto-placental factors will decrease maternal insulin sensitivity, ${ }^{13}$ and this will stimulate mother cells to use sources of fuels (energy) other than glucose such as free fatty acids, and this will increase supply of glucose to the fetus. ${ }^{7}$ Although, pregnancy is associated with increase in the beta-cell mass and increase in insulin level throughout pregnancy but certain pregnant women are unable to up-regulate insulin production relative to the degree of insulin resistance that develops in the second and third trimesters, and consequently become hyperglycemic, developing gestational diabetes. ${ }^{16,29}$ In pregnancy, the decreased insulin sensitivity is best characterized as a post-receptor defect resulting in the decreased ability of insulin to bring about glucose transporter (GLUT4) mobilization from the interior of the cell to the cell surface. ${ }^{9}$ Hyperglycemia in the early stages of pregnancy is associated with increased teratogenesis, which can occur in pregestational type 1 and 2 
diabetes. Cardiac and neural tube defects are the most common malformations observed in fetuses of pregestational diabetic mothers. ${ }^{38,40}$ The most notable cardiac defects are transposition of the great arteries, mitral and pulmonary atresia, double outlet of the right ventricle, tetralogy of Fallot, and fetal cardiomyopathy. ${ }^{10,25}$ Hyperglycemia during pregnancy can result in gestational diabetes in women with borderline or low pancreatic function. ${ }^{26-27}$ Gestational diabetes has been associated with obstetric and neonatal problems and usually occurs in the later stages of pregnancy, that is late second and third trimester. ${ }^{30-31}$ Gestational diabetes is associated with a range of maternal perinatal morbidities and mortalities including fetal macrosomia $(20 \%)$, stillbirths $(10-30 \%)^{33}$ hyperinsulinaemia and hypoglycaemia, but may also programme childhood obesity and adult onset cardiovascular disease and diabetes. ${ }^{23-24}$ In the mother, gestational diabetes increases the risk of developing type 2 diabetes later in life and some cardiovascular problem as hyperglycemia has been observed to destroy blood vessels. ${ }^{34}$ Gestational diabetes should be regarded as one of the complications of pregnancy; hence, pregnant women should be properly informed as to guard against it during pregnancy. ${ }^{22-23}$ The need for diet therapy and planned diet for pregnant women becomes very relevant and periodic screening is recommended of all pregnant mothers. Hyperglycemia is one sign of diabetes in pregnancy that can affect women with pre-existing Type 1 or Type 2 diabetes, or can develop during the pregnancy. ${ }^{2}$ Hyperglycemia during pregnancy, are identified as gestational diabetes, which affects around 1 to 3 percent of pregnancies generally. ${ }^{3}$ Hyperglycemia from any cause can seriously affect both mother and baby, and could increase the risk of complications in pregnancy, labour and after delivery in condition that it is not monitored properly. ${ }^{19}$ In conclusion the increasing frequency of blood glucose level to the border line in third trimester of pregnancy may predispose women to hyperglycemia or gestational diabetes and other adverse pregnancy outcomes. The random blood glucose level tends to increase during multiparty and at advance reproductive age.

\section{Acknowledgement}

The authors are grateful to the following; Mr Jibril Danladi of the Department of human Anatomy for his assistance in the analysis of the work and Mr Jimoh Abdulazeez of the Department of Human physiology Ahmadu Bello University, Zaria for his assistance in taking data.

\section{References}

[1]. Al-Noaemi M, Shalayel M, 2011 Pathophysiology of Gestational Diabetes Mellitus: The Past, The Present and the Future In: Gestational Diabetes. In: Tech, Janeza Tridne, Croatia. pp 91-114.

[2]. Ali S, 2011 Dornhorst A. Diabetes in pregnancy: health risks and management. Postgraduate Medical Journal, 87(1028):417-427.

[3]. Alwan N, Tuffnell DJ, West J. 2009 Treatments for gestational diabetes. Cochrane Database of Systematic Reviews, (3):CD003395.

[4]. Andersson DKG, Lundblad E, Svardsudd K, 1993 A model for early diagnosis of type 2 diabetes mellitus in primary health care. Diabetes Medicine 10:167-73.

[5]. Arulkumaran S, Sivanesaratnam V, Chatterjee A, Kumar P, 2010 Essentials of Obstetrics, $1^{\text {st }}$ edition, Jaypee brothers medical publishers New Delhi India pp-91.

[6]. Braak T, Evers EW, Willem IM, Erkelens D, Visser GH, 2002 Maternal hypoglycemia during pregnancy in type 1 diabetes: maternal and fetal consequences. Diabetes Metabolism Research Reviews. 18(2):96-105.

[7]. Catalano PM, Tyzbir ED, Roman NM, Amini SB, Sims EA, 1991 Longitudinal changes in insulin release and insulin resistance in non-obese pregnant women. American Journal of Obstetrics and Gynecology 165 1667-1672.

[8]. Catalano PM, Tyzbir ED, Allen SR, McBean JH, McAuliffe TL, 1992 Evaluation of fetal growth by estimation of neonatal body composition. Obstetrics and Gynecology 79 46-50.

[9]. Catalano PM, 2010 Focus Review on obesity, insulin resistance and pregnancy outcome. Journal of Reproduction, 140:365-371

[10]. Corrigan N, Brazil DP, McAuliffe F, 2009 Fetal cardiac effects of maternal hyperglycemia during pregnancy, Birth Defects Research And Clinical Molecular Teratology 85(6):523-30.

[11]. Dapaonte A, Guides F, Mosure D, Marineanu A, 1999 Management of Diabetic pregnant patients in a Tertiary center in the Developing world, International journal of Gynaecology and obstetrics, 64(2): 141-6.

[12]. David C, Richard AP, David H, et al 2011 Random blood glucose measurement at antenatal booking to screen for overt diabetes in pregnancy. Care Diabetes Journal 34:2217-2219.

[13]. Engelgau MM, Thompson TJ, Smith PJ, et al 1995 Screening for diabetes mellitus in adults: the utility of random capillary blood glucose measurements. Diabetes Care 18:463-6.

[14]. Glass RH, Kase NG, 1984 The endocrinology of pregnancy In: Clinical Gynecology Endocrinology \&Metabolism.3rd edition, Leon Speroff pp-271-305.

[15]. Guyton AC, Hall JE, 2011 Insulin, Glucagon, and Diabetes, In: Textbook of Medical Physiology, 11th edition, McGraw Hills, Elsevier Saunders Publication. ISBN: 0-7216-0240-1. pp. 961-970.

[16]. Hadden DR, 1998 A Historical Perspectives on Gestational Diabetes. From the Fourth International Workshop-Conference on Gestational Diabetes Mellitus. Diabetes Care journal. 21(2):298.

[17]. Horvath K, Koch K, Jeitler K, et al 2010 Effects of treatment in women with gestational diabetes mellitus: systematic review and meta analysis. British Medical Journal 40:c1395.

[18]. Jowett NI, Samanta AK, Burden A, 1987 Screening for diabetes in pregnancy: is a random blood glucose enough? .US National Library of Medicine National Institutes of Health. Diabetes Medicine 4(2):160-3.

[19]. Landon MB, Spong CY, Thom E, et al 2009 A multicenter, randomized trial of treatment for mild gestational diabetes. New England Journal of Medicine 2009; 361(14):1339-1348.

[20]. Marthins MI, Zaria and its region. Department of Geography Ahmadu Bello University, Zaria, 2006 : pp-41.

[21]. May WY, 2010 Physiological changes in pregnancy; Essentials of Obsterics edited by: Arulkumaran S, Sivanesaratnam V, Chatterjee A, Kumar P, first edition, Jaypee brothers medical publishers New Delhi India Ltd pp 41-49. 
[22]. Metzger BE, Lowe LP, Dyer AR, Trimble ER, Chaovarindr U, Coustan DR, Hadden DR, McCance DR, Hod M, McIntyre HD, Oats JJ, Persson B, Rogers MS, Sacks DA . Hyperglycemia and adverse pregnancy outcomes. N Engl J Med 2008; 358: 1991- 2002

[23]. Miroslav R, 2011 Gestational diabetes. In: Tech publishers, Janeza Tridne, Croatia, pp-146

[24]. Moore KL, Persaud TVN, 2008 Embryonic terminology in: The developing human, clinically oriented embryology, $8^{\text {th }}$ edition, Elsevier-Saunders, Philadelphia, USA pp 7.

[25]. Moore TR, 2010 Fetal exposure to gestational diabetes contributes to subsequent adult metabolic syndrome. American journal of Obstetrics and Gynecology, 202(6): 643-649.

[26]. Nolan CJ, 2011Controversies in gestational diabetes. Best Practical Results in Clinical Obstetrics and gynecology, 25(1):37-49.

[27]. Nwaoguikpe RN, Uwakwe AA, 2008 Blood glucose levels of pregnant women at different gestation periods in Aba area of Abia State of Nigeria Scientific Research and Essays, 3(8):373-375.

[28]. Persson B, Hansson U, 1993 Hypoglycaemia in pregnancy. Baillieres Clinicial Endocrinology Metabolism, 7(3):731-9.

[29]. Reick S, Kaestner KH, 2010 Expansion of beta-cell mass in response to pregnancy. Trends Endocrinology and Metabolism, 21(3):151-8.

[30]. Ryan EA, Enns L, 1988 Role of Gestational Hormones in the Induction of Insulin Resistance, Journal of Clinical Endocrinology and Metabolism., 67:341-347.

[31]. Saleh NM, Bener A, Al-Hamaq A, 2011 Prevalence of gestational diabetes and associated maternal and neonatal complications in a fast-developing community: global comparisons, International Journal of Women's Health, 2011(3): 367 - 73.

[32]. Sembulingam K, Sembulingam P, 2010 Endocrine functions of the pancreas In: Essentials of Medical Physiology $5^{\text {th }}$ edition. Jaypee brothers medical publishers, New Delhi, India, pp 398-407.

[33]. Setji, TL, Brown JA, Feinglos MN, 2005 Gestational Diabetes Mellitus, clinical diabetes, 23(1):1-5.

[34]. Solomon C, Seely E, 2001 Hypertension in pregnancy: a manifestation of the insulin resistance syndrome? Hypertension 37:232239.

[35]. Wendland EM, Torloni MR, Falavigna M, et al 2012 Gestational diabetes and pregnancy outcomes - a systematic review of the World Health Organization and International ion of Diabetes in Pregnancy Study Groups (IADPSG) diagnostic criteria. BMC Pregnancy Childbirth 12(1):23.

[36]. WHO, 1999 Definition, diagnosis and classification of Diabetes mellitus and its complications, a report of WHO consultation, Geneva, pp1-59.

[37]. WHO, 2006 Definition and Diagnosis of Diabetes Mellitus and Intermediate Hyperglycemia, [online], available at http://www.who.int/diabetes.com Retrieved 2011-02-20.

[38]. WHO, 2009 "Reproductive Health and Research Publications: Making Pregnancy Safer". Regional Office for South-East Asia. 2009. Retrieved March 15th 2013.

[39]. World Health Organization 2013 Report on the Diagnostic criteria and classification of hyperglycemia first detected in pregnancy, pp-1-20

[40]. Varghesel R, Thomas B, Al-Hail M, et al 2010 The prevalence, risk factors, maternal and fetal outcomes in gestational diabetes mellitus. International journal of drug development and research, 4(3):356-368. 